\title{
Effects of very small doses of urine on acceleration and delay of sexual maturation in female house mice
}

\author{
L. C. Drickamer
}

Biology Department, Williams College, Williamstown, Massachusetts 01267, U.S.A.

\begin{abstract}
Summary. Four types of chemosignal donors were used: adult intact males, grouped adult intact females, pregnant females and lactating females. A daily dose of $0.001 \mathrm{ml}$ urine was sufficient to produce the same degree of acceleration or delay known to occur with whole urine from each donor type. With $0.00001 \mathrm{ml}$ the age of puberty did not differ from that of water-treated controls for any of the treatments. With the intermediate, $0.0001 \mathrm{ml} /$ day dose, the results were variable, depending upon the donor type. The results indicate that for young mice daily exposure to extremely small quantities of urine can influence the physiological events accelerating or delaying puberty.
\end{abstract}

\section{Introduction}

Urine from four different donor types has been shown to accelerate or delay puberty in female house mice. Urine from adult males accelerates puberty (Vandenbergh, 1969); urine from grouped females delays sexual maturation (Drickamer, 1977); and urine from pregnant or lactating females accelerates puberty (Drickamer \& Hoover, 1979). In a previous series of experiments Drickamer (1982) demonstrated that, for urine from males and grouped females, dose levels as small as 0.001 $\mathrm{ml} /$ day were sufficient to produce, respectively, acceleration and delay of sexual maturation. For urine from pregnant and lactating females, there was an overlapping pattern; 0.01 and 0.005 $\mathrm{ml} /$ day were sufficient to accelerate puberty, but smaller doses $(0.003$ and $0.001 \mathrm{ml})$ did not result in mean ages for first oestrus that were significantly earlier than those of control females treated with water. Additional data on dose levels are needed to understand the mechanisms involved in altering the age of puberty and the ecology of house mouse populations. How sensitive are the physiological mechanisms of the young females to the urinary chemosignals? How much urine must a mouse encounter in nature to activate the effects on reproductive physiology? The present report deals with an assessment of dose levels for the four chemosignals affecting puberty, using serial dilution to achieve very small amounts for daily administration to test females.

\section{Materials and Methods}

The mice used in these experiments were from a randomly-bred closed colony of ICR/Alb house mice (Mus musculus). All colony and test mice were housed in shoe-box cages made of polypropylene $(15 \times 28 \times 15 \mathrm{~cm})$ with opaque sides and fitted wire lids. Bedding of ground wood shavings was used and that in each cage was changed once per week. Wayne Lab-Blox and water were supplied ad libitum to all mice. Colony and experimental rooms were maintained at $21-25^{\circ} \mathrm{C}$ and $30-60 \%$ relative humidity on a 12-h light/12-h dark light regimen with lights on at $06: 00 \mathrm{~h}$.

(C) 1984 Journals of Reproduction \& Fertility Ltd 
Pregnant female mice were isolated into individual cages during the last week before parturition. All cages were then checked daily for litters. On the day after birth each litter was counted and all the young were sexed. Each litter was reduced to 10 young, including at least 3 males. Litters of less than 10 young were discarded. Mice were weaned 21 days after birth and were immediately assigned to a treatment according to a random sequence.

Each mouse was examined daily from Day 21 until the occurrence of vaginal introitus. Starting on the day of vaginal introitus, a vaginal lavage was taken each day until the occurrence of first vaginal oestrus. The wet-mount vaginal smears were examined immediately with a microscope and the cellular contents were judged to determine the stage of the oestrous cycle according to the criteria of Rugh (1968) and Vandenbergh (1969).

Four experiments were conducted, one with each of the four urinary chemosignals - the design, procedures and analyses for each were identical, except for the donor mice that provided the urine. For each urine source fresh urine was collected daily from 10-15 donors by holding the mice over a Petri dish and gently squeezing the flanks. The urine was then serially diluted 1:9 to obtain the graded sequence of doses used. Urine donors for the respective experiments were singly-caged intact males, intact females ( $\mathrm{N}=8 \mathrm{mice} /$ cage), pregnant females caged individually (used for urine collection between Days 8 and 18 of pregnancy timed by finding seminal plugs), and lactating females caged individually (used for urine collection 8-18 days post partum). All urine donors were aged 70-150 days at the time of the experiment. Males and grouped females were caged in the designated conditions at least 3 weeks before the start of the experiment. Separate Petri dishes and syringes were maintained for each type of urine used. In each experiment 5 treatment groups were used (15 mice/treatment); (1) $0.05 \mathrm{ml}$ water, (2) $0.01 \mathrm{ml}$ urine, (3) $0.001 \mathrm{ml}$ urine, (4) $0.0001 \mathrm{ml}$ urine, and (5) $0.00001 \mathrm{ml}$ urine. Each urine dose was administered daily in a volume of $0.05 \mathrm{ml}$ water on the external nares using a Hamilton syringe. Treatment continued until the occurrence of first vaginal oestrus. Each young female was monitored daily until the occurrence of first oestrus.

\section{Results}

Separate analyses-of-variance revealed significant dose effects for each urine type (Table 1). For male urine and urine from grouped females dose levels as low as $0.0001 \mathrm{ml} /$ day were sufficient to alter the age of maturation, but $0.00001 \mathrm{ml} /$ day did not result in mean ages for first oestrus different from those of water-treated controls. For pregnant and lactating females the pattern of significant differences was such that doses of $0.001 \mathrm{ml} /$ day did produce acceleration of maturation, but smaller amounts were not effective in hastening sexual development.

Table 1. Mean age in days ( \pm 1 s.e.m., 15 mice/treatment) for first vaginal oestrus in young female house mice painted daily on the external nares with various doses of urine from one of four donor sources

\begin{tabular}{|c|c|c|c|c|}
\hline \multirow[b]{2}{*}{$\begin{array}{l}\text { Dose of urine } \\
(\mathrm{ml})\end{array}$} & \multicolumn{4}{|c|}{ Donors } \\
\hline & Males & $\begin{array}{l}\text { Grouped } \\
\text { females }\end{array}$ & $\begin{array}{l}\text { Pregnant } \\
\text { females }\end{array}$ & $\begin{array}{l}\text { Lactating } \\
\text { females }\end{array}$ \\
\hline 0 (water control) & $35.2(0.8)$ & $34.8(0.8)$ & $33.6(0.9)$ & $33.5(0.8)$ \\
\hline 0.00001 & $32 \cdot 7(1 \cdot 0)$ & $34 \cdot 3(1 \cdot 2)$ & $31.3(1.0)$ & $32 \cdot 0(1 \cdot 1)$ \\
\hline 0.0001 & $31.8(0.8)$ & $38.2(1.2)$ & $32.5(0.6)$ & $31.9(1.0)$ \\
\hline 0.001 & $29.9(0.7)$ & $37 \cdot 3(1 \cdot 2)$ & $30.5(0.8)$ & $28.9(0.4)$ \\
\hline 0.01 & $29 \cdot 2(0.6)$ & $37.2(0.9)$ & $29.5(0.7)$ & $28.8(0.5)$ \\
\hline $\mathbf{F}$ & $11 \cdot 286$ & 3.330 & 3.568 & 5.936 \\
\hline d.f. & 4,70 & 4,70 & 4,70 & 4,70 \\
\hline$P$ & $<0.01$ & $<0.025$ & $<0.025$ & $<0.01$ \\
\hline
\end{tabular}

Means in each column not connected by the same vertical line are significantly different at the 0.02 level (Duncan's new multiple range test). 


\section{Discussion}

The internal mechanisms of young female mice involved in reception and translation of the urinary chemosignals which alter the timing of sexual maturation are extremely sensitive. For urine from males and from grouped females these physiological events are altered when only 1 part in 10000 is the urine containing the chemosignal. For urine from pregnant and lactating females a dose of 1 part in 1000 is sufficient to produce measurable changes in these physiological events in recipient females.

The present data for urine from pregnant and lactating females differ from those of Drickamer (1982) wherein $0.001 \mathrm{ml}$ was not a sufficient daily quantity of urine to affect an acceleration of puberty. I have no complete explanation for this roughly 10 -fold difference in the apparent effective dose. One suggestion involves the fact that the earlier work concerning urine from pregnant and lactating females was conducted in the fall and early winter months, whereas the present data were gathered during summer. There may be a differential seasonal sensitivity of the recipient females or some seasonal variation in the potency of the chemosignals released in the urine by the pregnant and lactating females.

With regard to free-living house mice it seems probable that young females encountering urine from these particular sources would be exposed to enough active chemosignal to hasten or delay puberty, providing they were exposed over a sufficient number of days. For acceleration by urine of males 3 days of exposure are needed (Colby \& Vandenbergh, 1974), and for the delay of puberty by urine from grouped females at least 4 days and possibly as many as 7 days of exposure are required (Drickamer, 1977). For urine from pregnant and lactating females, 3 days of exposure are sufficient to hasten sexual maturation (Drickamer, 1984). Thus, young female house mice could be affected by one or more of these substances if they remained in their natal location for a sufficient period of time after weaning, or, if they departed from the natal site, whenever they assumed a new, stable residence. Bronson (1979) has argued that the urinary chemosignal effects may delay puberty until the young females have relocated from the natal site to another breeding unit. However, there are as yet insufficient data on the dispersal and activities of young house mice in free-living populations to reach any firm conclusions on this matter.

While these mammalian chemosignals are not apparently effective in the dose ranges that have been reported for some insect pheromones (Schneider, 1966), the chemosignals are having potent physiological effects when present in the environment in extremely small amounts.

This research was supported, in part, by a National Institutes of Child Health and Human Development Award No. HD-08585 from the United States Public Health Service.

\section{References}

Bronson, F.H. (1979) The reproductive ecology of the house mouse. Q. Rev. Biol. 54, 265-299.

Colby, D.R. \& Vandenbergh, J.G. (1974) Regulatory effects of urinary pheromones on puberty in the mouse. Biol. Reprod. 11, 268-279.

Drickamer, L.C. (1977) Delay of sexual maturation in female house mice by exposure to grouped females or urine from grouped females. J. Reprod. Fert. 51, 7781.

Drickamer, L.C. (1982) Acceleration and delay of first vaginal oestrus in female mice by urinary chemosignals: dose levels and mixing urine treatment sources. Anim. Behav. 30, 456-460.

Drickamer, L.C. (1984) Acceleration of puberty in female mice by a urinary chemosignal from pregnant or lactating females: timing and duration of stimulation. Devl Psychobiol. (in press).

Drickamer, L.C. \& Hoover, J.E. (1979) Effects of urine from pregnant and lactating female house mice on sexual maturation of juvenile females. Devl Psychobiol. 12, 545-551.

Rugh, R. (1968) The Mouse, Its Reproduction and Development. Burgess Publ. Co., Minneapolis.

Schneider, D. (1966) Chemical sense communication in insects. Symp. Soc. exp. Biol. 20, 273-297.

Vandenbergh, J.G. (1969) Male odor accelerates female sexual maturation in mice. Endocrinology 84, 658660.

Received 24 October 1983 